\title{
Thoughts Shot Forth in Vain (Eur. Hecuba 599-602)
}

\section{Tatiana V. Kostyleva}

National Research University Higher School of Economics (HSE) in St Petersburg, 123 Gribojedov Canal Emb., St. Petersburg, 190068, Russian Federation; tkostyleva@hse.ru

For citation: Tatiana V. Kostyleva. Thoughts Shot Forth in Vain (Eur. Hecuba 599-602). Philologia Classica 2019, 14(1), 144-148. https://doi.org/10.21638/11701/spbu20.2019.111

In this piece, attention is once again drawn to the locus classicus of Euripidean sententious outbursts, lines 599-602 put in the mouth of Hecuba mourning her daughter Polyxena. Suggested for bracketing by W.M. Sakorraphos in 1893 and athetised by J.Diggle (1984) and D. Kovacs (1995) in their respective editions (although not in the editions of J. Gregory (1999) and K. Matthiessen (2010), the lines (and the whole passage 592-602) have also shouldered a weight of Euripidean Weltanschauung doctrines built on their slender frame. A brief overview of scholarly judgment, often overexacting, prompts one to occupy the middling ground allowing both for the possibility of the genuine character of the lines 599-602 and their relevance in context (and not only expressing the ideas current in Euripides' times) with both birth and upbringing contributing to virtuous character. The metaphor in line 603 should not be considered a brave mannerism, or a marginal remark of some critic, but a marker of a change of topic, its archery imagery well on the side of trite.

Keywords: Attic tragedy, Euripides, Hecuba, textual criticism, athetesis

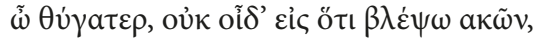

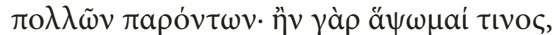

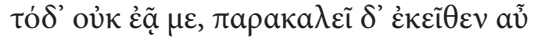

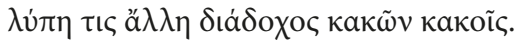

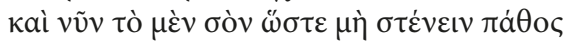

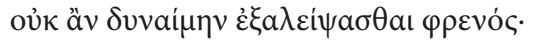

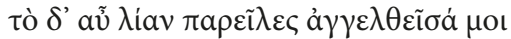

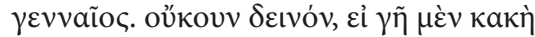

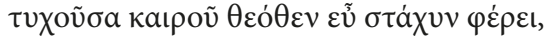

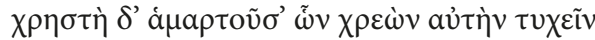

(C) St. Petersburg State University, 2019 


\title{
599-602 del. Sakorraphos ${ }^{1}$
}

\begin{abstract}
"Daughter, I don't know to which of the ills to attend, there being so many. If I lend my heart to one, this [ill] doesn't abate, but a new grief ever calls on me from elsewhere, a sorry successor to sorrows. And now I am hardly able to take my mind off your death and not to lament it. But you have relieved me of excessive grieving having proved yourself to be noble. Is it not perplexing that while poor soil having received its due from the god in good season, yields good crop, and fertile soil having not received its due fails to bear a good harvest, among men it is always like this: a mean man is ever mean, rain or shine, and a noble man ever noble, and his nature never spoilt in misfortunes, but remains ever good? [But is it the parents or maybe also the ways of upbringing that cause the difference? Yet being well-brought does its bit for the acquisition of nobility too. If one learns it well, one at least knows the mean, having measured it against the standard of the noble.] But my mind has shot these thoughts forth in vain."
\end{abstract}

Hecuba has just received the news of the death of her last surviving daughter Polyxena and seems to have found some peace in the description of the nobility and beauty of

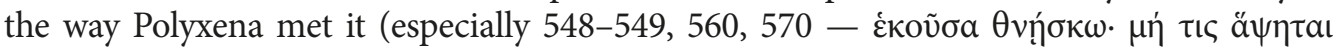

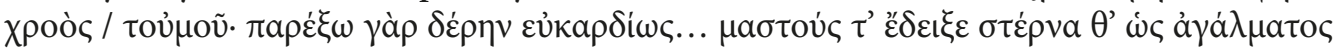

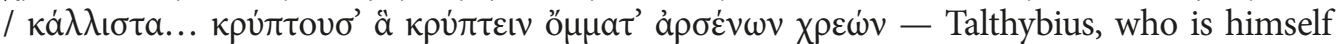
crying, has touched all the right strings with his narrative), since she spends the following tenodd lines musing on the nature of man. Brimming with grief, she can still find in it a source for reasoning - 'flagship' lines 591-602 are a staple of gnomologia (Hecuba is a favourite, with 11 passages cited in Orion, ${ }^{2}$ and 14 in Stobaios ${ }^{3}$ ). These (and especially 599-602, where her musings tend to become even more general) are the versus suspecti, over which scholars lock and fight. The division (taken to extreme) tends to be threefold: those who, on the rebound, spurn a confirmed moraliser in Euripides and hence are content to expose each general reflection as manifestation of this flaw; radical critics who hunt down every digression, illogicality or lapse and suspect an interpolation catering to the demands of a different audience thus often subjecting the text of the tradition to what F. Ferrari called "attraverso violente normalizzazioni"; ${ }^{4}$ conservative critics who try to explain away each and every case either out of the logic of situation, character, and context, or out of facts of life external to the play. ${ }^{5}$

${ }^{1}$ I cite the text and (relevant part of the) apparatus as edited by Diggle 1984, 366-367, who never misses an opportunity to relieve Euripides of a line or two. Kovacs 1995 ad loc. suspects these lines. Page 1934, ad loc., however, does not put this passage into his actors' interpolations category, or indeed into any intrusive lines category. The closest one to ours, which he believes to be an histrionic interpolation, is 606-608. He does admit that more can be discovered.

2 Haffner 2001.

3 Wachsmuth, Hense 1884-1912.

${ }^{4}$ Ferrari 1986, 62.

${ }^{5}$ For an overview and judicious assessment, see Heath 1987, 40-68. 
The sequence of 592-598 and 599-602 was first exposed as contradictory by H. Weil who believed Euripides bluntly spoke his mind forgetful both of the situation and the character, a mere mouthpiece: « cette noblesse de sentiments que les coups de la fortune ne sauraient altérer, tient-elle à la naissance ou à léducation? Euripide fait ici une certaine part à cette dernière $»{ }^{6}$ In the wake of Weil's remark, the bracketing of 599-602 was proposed by G.M.Sakorraphos in 1893 . He condemned the lines on the following grounds: "indigni Euripide... pugnant enim non modo cum prioribus, sed etiam cum tota Euripidi doctrina. saepe enim vidimus praesertim Euripidem hanc quaestionem tractasse, num educatio hominis naturam vincere vel corrigere possit et sim. in iis omnibus locis, ut ratio postulat, natura opponitur educationi sive parentibus, hoc autem loco parentes et educatio inter se opponuntur". It is notoriously hard to pin down a dramatist's doctrina and to pass judgement on whether or not any given verse befits the poet tilts precariously on the side of personal taste. While for Weil an outbreak in 599-602 is what he may well call Euripides' doctrina, Sakorraphos finds doctrina as it is in 599-602 distorted, introducing an opposition which is

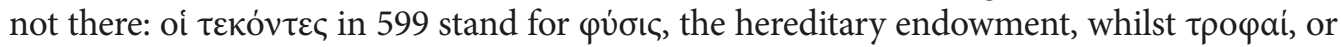
else трофп - the upbringing and the environment. Having little sympathy for those who come to far-reaching conclusions churning a Euripidean Weltanschauung, one is naturally prompted to think that Euripides really understood that both are contributing factors. ${ }^{8}$

So far, the problem is that while the traditional aristocratic beliefs in nobility by birth (595-598) are in line with Hecuba's not easily forgotten queenly status, the shift to instruction in nobility and its teachability in $599-602$ is a somewhat alien element. W. S. Barrett, a terse critic, discussing 191-197 in the Hippolytos, equally suspect on the grounds of dramatic irrelevance, saw reasons for excision of 599-602 not in the "glaring irrelevancy" of the lines (he rightly observes that Euripides' "reputation for moralising is largely exag-

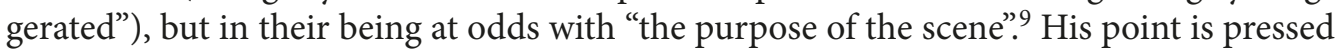
home in a short piece (a posthumously published draft) devoted especially to these lines. Setting off with "599-602 are absurd here; the trouble is not that Hekabe is made to phi-

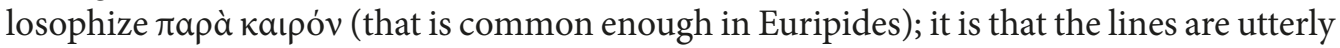
and disastrously irrelevant to her first and genuine point of 592-8", he suggests they come from "a context very different from ours", the one of tapping the "source of our knowledge of right and wrong", whereas in 592-598 Hecuba is concerned with "consistency in virtue and vice", not with any source of our knowledge of it. ${ }^{10}$

The lines have their champions just as well. J.Gregory, the author of a relatively recent commentary on the play, anchors what follows on the adjective $\gamma \varepsilon v v$ vĩo (592), indeed placed in an emphatic enjambement, suggesting it "lends plausibility to the calm reflections that follow", only to call these later on "a general reflection of major thematic importance".11 K. Matthiessen in his posthumously published most recent commentary on Hecuba, likewise benevolent, is inclined to catch a glimpse of the times, observing „sie [diese Reflexion] gehört in den Kontext der zeitgenössischen Diskussionen über dieses Thema, das Eur. auch sonst öfters berührt ${ }^{12}{ }^{12} \mathrm{Ch}$. Collard lauded the excision in his review of Diggle’s OCT

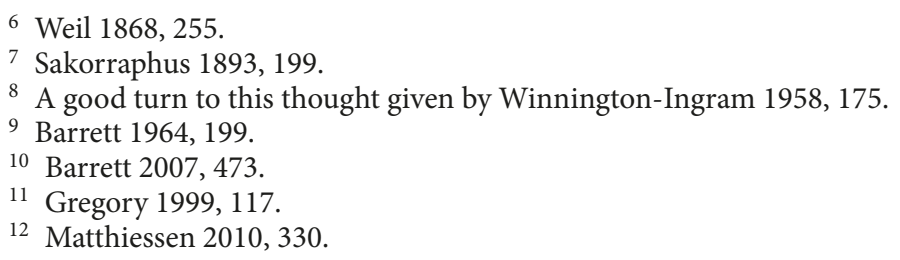


("It is salutary to be confronted with the deletion of half this passage. One sees, Hecuba's point is made as well by $592-598$ "), ${ }^{13}$ while in his commentary he defends the lines on the grounds of their relevance in context: Hecuba is talking as Polyxena's mother and teacher, who moreover "learns from her daughter's example". ${ }^{14} \mathrm{~J}$. C. Kamerbeek, reviewing the same OCT volume, did remark that Diggle "is too prone to assume interpolation" also in "the seemingly irrelevant digressions in the rheseis of ratiocinating heroines which are characteristic of Euripidean dramatis personae echoing the discussions of the time" and went on to call the deletion "an instance of downright wrong athetesis" of a general reflection. ${ }^{15} \mathrm{~W}$. Biehl held 599-602 to be a reasonable development of the reflective lines $592-598^{16}$ thus fitting the context, and K. Matthiessen believed the lines 599-602 to be indispensable: „weil hier der Schritt vom Glauben an die absolute Dominanz der Anlagen hin zu der Auffassung vollzogen wird, dass die Tugend, jedenfalls in gewissem Umfang, lehrbar ist. Das ist zugleich ein Schritt vom aristokratischen Menschenbild Pindars (Olympien 2,86-88, 9, 100-08) zu dem des Sokrates und der Sophisten, also genau das, was man bei Eur. erwarten sollte“.17

So far, so good. Gregory, however, made a valid point in her commentary having observed in passing that while "the agricultural analogy is a commonplace in Greek literature, it is generally framed to emphasize similarities rather than differences". ${ }^{18}$ The pool of examples (seasonal changes, as you sow you shall mow) could be further supplied by

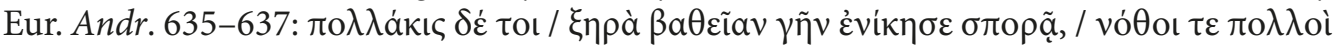
$\gamma \nu \eta \sigma i \omega v$ á $\mu \varepsilon \dot{i} v o v \varepsilon \varsigma$, 'as barren land can often outdo rich soil in issue, so good many bastards are nobler than legitimate children' (El. 367-372 are very similar). In our case, poor soil can yield an ample harvest should it get the sun and rain at right times, while rich soil

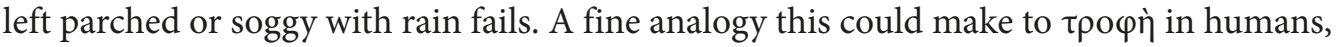
but Hecuba's point is different: human beings, unlike responsive soil, remain steadfast both in virtue and vice inborn. Should we follow those who defend 599-603 and say with W. Schadewaldt that "das Problem wird regelrecht diskutiert "19 to cover the issue of bringing up in excellence? Is it not a hairsplitting argument to pursue that 599-603 have at stake not the ability to be consistent due to proper upbringing, but the source of our knowledge of virtue and vice, as W. S. Barrett holds, and are alien matter?

Line 603 also poses a problem. It is in all probability genuine, since there are parallels of thoughts 'let fly' in aspiration, as in Eur. Tro. 643-644 (with a Genitive, standard use

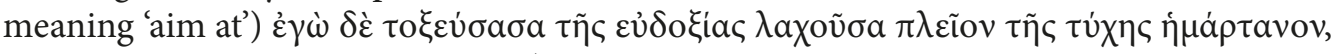

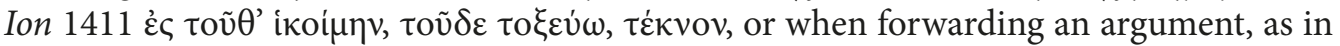

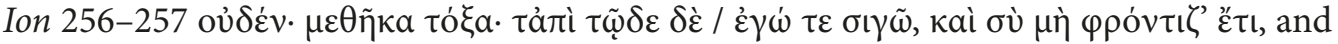

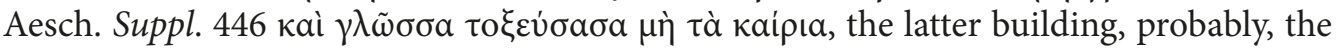

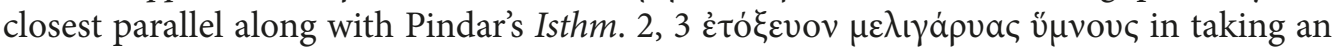
Accusative (hence not necessarily a Euripidean idiom). ${ }^{20}$ The scholiasts also did not stum-

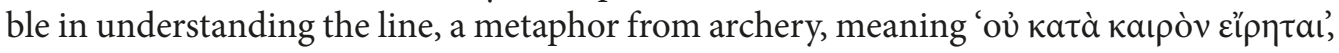
but uneasily suggested that Euripides here is engaging in tongue-in-cheek commenting

13 Collard 1986, 23.

14 Collard 1991, 162 ad loc.

15 Kamerbeek 1986, 93, 101.

16 Biehl 1997, 120-122.

17 Matthiessen 2010, 330-331.

18 Gregory 1999, 117.

19 Schadewaldt 1926, 139.

20 Noted already in Collard 1991, 163; Matthiessen 2010, 331. 
on his own penchant for the sentiment above. ${ }^{21}$ This view is shared by Ch. Collard, who suggests Euripides is "gently mocking his own indulgence in such speculation". 22 Gregory and Matthiessen both believe 603 to mark a transition from a general reflection to involvement with issues at hand. ${ }^{23}$ In the light of doubt cast over this line in the scholia, could it be a marginal remark (iambic trimetre as it is) left by some Alexandrian or Byzantine critic? It is unlikely, and the line can still be a mere transition phrase.

And a mere technicality, with excision adopted, the resulting immediate leap from 598 to 603 be seamless? Would it not make Hecuba wave off as "vain" the thoughts that consoled her, namely, that good noble nature of Polyxena did not falter in calamitous circumstances? Would it rather be more appropriate for her to curtly check herself after 599-602, the digression on instruction in virtue, painful to her, who has brought up and lost so many children in vain? Guesswork on the irrelevance of 599-602 may continue, what remains is that Hecuba's own nobility will soon be put to test (her ignoble deed was seen differently through the ages, with the Renaissance men finding no fault with her revenging on Polymnestor and his children). Was it that Euripides still wanted to undercut her judgment and prove by her action that there is, in fact, a limit to what a person could bear?

\section{References}

Barrett, W.S. (ed., comm.) Euripides, Hippolytos. Oxford, OUP, 1964.

Barrett, W. S. Greek Lyric, Tragedy and Textual Criticism. Oxford, OUP, 2007.

Biehl, W. Textkritik und Formanalyse zur Euripides Hekabe. Heidelberg, 1997.

Collard, Ch. Review: Euripidis Fabulae, Tomus I, CR 36, 1986, 23.

Collard, Ch. (comm.) Euripides, Hecuba. Warminster, 1991.

Diggle, J. (ed.) Euripidis Fabulae. Oxford, OUP, 1984.

Diggle, J. Review of A. N. Michelini, Euripides and the Tragic Tradition and D. Kovacs, The Heroic Muse. AJPh 110, 1989, 360.

Dindorf, W. (ed.) Scholia Graeca in Euripidis tragoedias. T. I. Oxonii, 1863.

Ferrari, F. Recensione e Euripidis Fabulae, ed. J. Diggle, I e II, Oxonii 1981 e 1984. RFIC 114, 1986, 61-68.

Gregory, J. (comm.) Euripides, Hecuba. Atlanta, 1999.

Haffner, M. (ed.) Das Florilegium des Orion, Stuttgart, 2001.

Heath, M. Iure principem locum tenet: Euripides' Hecuba. Bulletin of the Institute of Classical Studies 34, 1987, 40-68.

Kamerbeek, J.C. Rereading Euripides in the New Oxford Text (Tom. I). Mnemosyne 39, 1986, 92-101.

Kovacs, D. (ed., transl.) Euripides I. LCL 484. Cambridge, Mass., CUP, 1995.

Matthiessen, K. (ed., komm.) Euripides Hekabe. Berlin, de Gruyter, 2010.

Page, D. L. Actors' Interpolations in Greek Tragedy. Oxford, OUP, 1934.

Sakorraphus, G. M. Spicilegium observationum criticarum ad scriptores Graecos. Mnemosyne 21, 1893, 196-201.

Schadewaldt, W. Monolog und Selbstgeschpräch, Untesuchungen zur Formegeschichte der griechischen Tragödie. Berlin, 1926.

Schwarz Ed. (coll., rec., ed.) Scholia in Euripidem. Vol. I. Berolini, 1891.

Snell B., Maehler H. Pindari carmina. Leipzig, Teubner, 1980.

Wachsmuth, C., Hense, O. (ed.) Ioannis Stobaei anthologium. Weidmann, 1884-1912.

Winnington-Ingram, R.P. Hippolytus: A Study in Causation, in: Entretiens sur l'antiquité classique. Tome VI. Euripide. Vandoeuvres-Genève, 1958. 169-192.

21 Dindorf 1863, 371; Schwarz 1891, 56.

22 Collard 1991, 163.

${ }^{23}$ Gregory 1999, 118; Matthiessen 2010, 331. 